\title{
The Crevice Corrosion of 316L SS Alloy in NaCl Solution at Different Applied Potentials
}

\author{
Sanaa T. Arab', Mohammed I. Abdulsalam², Huda M. Alghamdi' ${ }^{1}$ Khadijah M. Emran ${ }^{3}$ \\ ${ }^{1}$ Department of Physical Chemistry, KAU, Jeddah, KSA \\ ${ }^{2}$ Department of Chemical and Materials Engineering, KAU, Jeddah, KSA \\ ${ }^{3}$ Department of Chemistry, Taibah University, Al-Madinah Al-Monawarah, KSA \\ Email: dr.s.arab@hotmail.com, starab@kau.edu.as, hudaalghamdi@hotmail.com, \\ kabdalsamad@taibahu.edu.sa
}

Received 22 January 2014; revised 22 February 2014; accepted 1 March 2014

Copyright (C) 2014 by authors and Scientific Research Publishing Inc.

This work is licensed under the Creative Commons Attribution International License (CC BY).

http://creativecommons.org/licenses/by/4.0/

(c) (i) Open Access

\begin{abstract}
316L SS alloy was tested under different applied potentials to study the susceptibility of this alloy to crevice corrosion. XPS measurements have been carried out to detect and define the products which formed on the surface of $316 \mathrm{LSS}$ in $3.5 \% \mathrm{NaCl}$ at room temperature at applied potential = $200 \mathrm{mV}$ SCE. The formation of $\mathrm{Fe}, \mathrm{Cr}$ and Mo compounds were found, and these compounds play a great role in protecting the alloy which was found. The boundaries of the corroded area under washer teeth are in agreement with IR drop. The potentiodynamic technique is also studied to examine the overall corrosion behavior of $316 \mathrm{LSS}$.
\end{abstract}

\section{Keywords}

Crevice Corrosion, 316L SS, Applied Potentials, Potentiostatic Measurements, Potentiodynamic Measurements, XPS Measurement, IR Drop

\section{Introduction}

316 LS is an austenitic stainless steel alloy containing at least $17 \%$ Cr with some alloying elements additions in varying concentrations. It has a high corrosion resistance due to the passive film existing on the alloy. Its passivity depends on the environment conditions. The common type of corrosion which causes failure in $316 L$ SS is the localized corrosion which leads to breakdown the passive film. One of the localized corrosions is the crevice corrosion which occurs in narrow openings or spaces between two metal surfaces or between metals and non 
metal surfaces [1]. The susceptibility of 316L SS to localized corrosion depends on applied potential at the outer surface, electrolyte resistivity, crevice length, crevice opening dimension, $\mathrm{pH}$ value, oxygen in the crevice electrolyte and temperature [2].

In the case of applied potential at the outer surface, the cathodic reaction rate did not limit the anodic reaction rate due to the potentiostat used to control the applied potential at the outer surface.

There are two models explaining the crevice corrosion process: CCS model and IR drop. CCS model assumes that the sole cause for the localized attack is related to compositional aspects, e.g., the acidification or the migration of aggressive ions into the crevice solution. These changes in the solution composition can cause breakdown the passivation film and promote acceleration and auto catalyzation of crevice corrosion [3]-[5]. The CCS theory predicts that the most severe attack will occur at the deepest part of the crevice, i.e., the most occluded portion [6].

IR drop assumes that crevice corrosion is caused by the potential drop which placed the local electrode potential existing on the crevice wall in the active peak region of the polarization curve. Separation between the anodic and cathodic reactions is necessary for the occurrence of crevice corrosion by the IR drop mechanism [3] [7]-[9]. $I R$-drop theory predicts the most severe attack at intermediated distance from the crevice mouth [10]-[12].

The aim of this study is to determine the susceptibility of 316L SS alloy at different applied potentials in 3.5\% $\mathrm{NaCl}$. XPS technique was used to identify the constituent species of corrosion products. 316L SS alloy was also studied using potentiodynamic technique. The morphology of the corroded surface under the washer tooth was discussed.

\section{Experimental}

For potentiostatic study, a rectangular-shaped specimen with $60 \mathrm{~mm} \times 30 \mathrm{~mm} \times 3 \mathrm{~mm}$ exposed areas was used. The specimen has a hole in the center $(7 \mathrm{~mm}$ diameter). This hole was used for the attachment of the multiple crevice test assembly. Another smaller hole on the top of the specimen was used for electrical contact using a titanium wire. The specimen was finally polished to 1000-silicon carbide paper then it was cleaned and degreased by ultrasound using acetone. The compositions of 316L SS alloy are listed in Table 1.

A multiple crevice test assembly made of Teflon from Metal Samples Co. Each washer has 20 teeth. Circular disc of $25 \mathrm{~mm}$ diameter was cleaned and degreased by ultrasound using double distilled water. The multiple crevice washers were bolted to both sides of each specimen using screw and nuts (made of Titanium). The torque value which used in this study is 2.5 in $l b f$. The screw bolt was inserted in a plastic tube to protect it from the solution (Figure 1(a)).

For potentiodynamic study, the sample was in square plate chap of $(1.4 \times 1.4 \mathrm{~cm})$. It was finally polished to 1200 silicon carbide papers, cleaned and degreased using double distilled water. A copper wire was attached to the specimen from the back by soldering. This wire was connected to the potentiostat. The sample was placed in a cylindrical mold then epoxy resin was poured inside the mold over the sample. After the resin had dried, the specimen was polished from the front side to expose the alloy sample. The crevice between metal-non-metal in the front side was masked using a resin (from Shin Etsu) as shown in (Figure 1(b)). The samples were also, cleaned using de-ionized water.

Corrosion cell (Figure 2) containing $1000 \mathrm{ml}$ of aerated $\mathrm{NaCl}$ solution (3.5\%) was equipped with carbon counter electrode. Salt bridge with Luggin capillary was used to connect the reference electrode to the corrosion cell. Test solution was used in the salt bridge to avoid chloride concentration changes in the test solution during the study. The potential was measured using a Saturated Calomel Electrode (SCE). The corrosion cell was connected to PC14/750 Gamry potentiostat for the potentiostatic and potentiodynamic studies. Susceptibility of $316 L$ SS alloy at different applied potentials was tested using potentiostatic measurment. Effect of applied potential was tested at values $-200,-50,0,50$ and $200 m V_{S C E}$. Chemical compositions on 316 SS surface after the study were defined by XPS using a multi-technique surface analysis system (MAX200, Leybold).

The potentiodynamic technique was used to examine the overall corrosion behavior of 316L SS. Potentiody-

Table 1. Chemical composition (\%wt) of the studied 316L SS alloy.

\begin{tabular}{ccccccccccccc}
\hline $\mathrm{C}$ & $\mathrm{Cr}$ & $\mathrm{Cu}$ & $\mathrm{Mn}$ & $\mathrm{Mo}$ & $\mathrm{Ni}$ & $\mathrm{N}$ & $\mathrm{P}$ & $\mathrm{Si}$ & $\mathrm{S}$ \\
\hline 0.030 & $16.0-18.0$ & $0.5-1$ & 2.0 & $2.0-3.0$ & $10.0-14.0$ & 0.10 & 0.045 & 0.75 & 0.03 & Balance \\
\hline
\end{tabular}




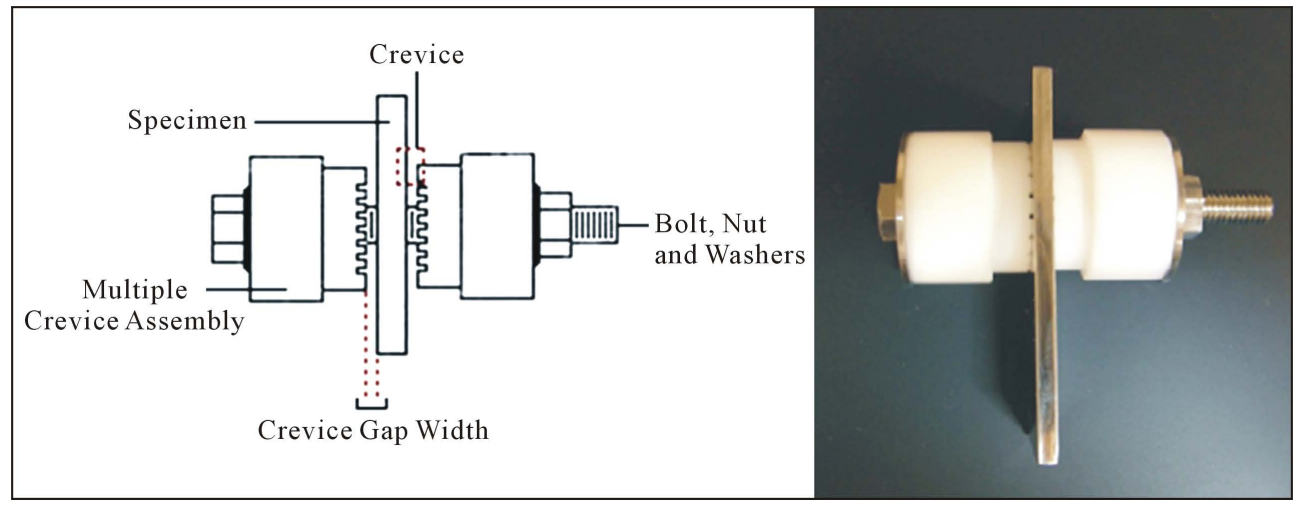

(a)

(b)

Figure 1. Schematic and photograph of the crevice assembly used in the study.

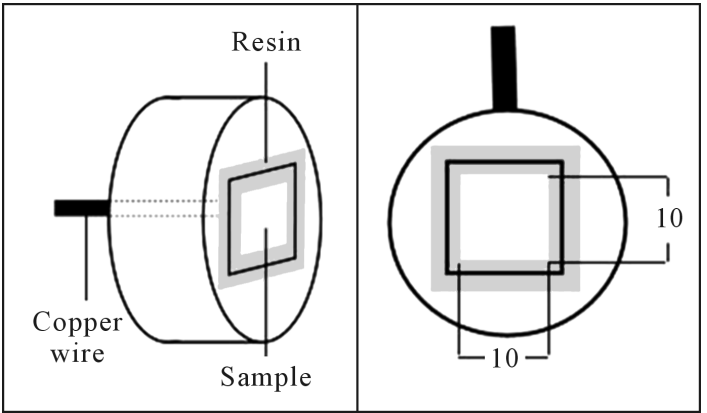

Figure 2. Schematic of the specimen used in potentiodynamic experiments and its dimensions in $\mathrm{mm}$.

namic potential sweep rate $(0.1667 \mathrm{mV} / \mathrm{s})$ was applied according to ASTM standard G5-94 [13] with change in potential from -600 to $+1200 m V_{S C E}$. Potentiostatic and potentioynamic Tests were run at room temperature $\left(25^{\circ} \mathrm{C}\right)$.

\section{Results and Discussion}

\section{Potentiostatic Measurements}

Crevice corrosion susceptibility results from potentiostatic tests in $3.5 \% \mathrm{NaCl}$ solution are summarized in Table 2.

$316 L$ SS sample did not show any crevice attack on the surface under the environmental conditions in 3.5\% $\mathrm{NaCl}$ at room temperature $\left(25^{\circ} \mathrm{C}\right)$ at applied potentials of $-200,-50$ and $0.0 \mathrm{~m} V_{S C E}$, or under the crevice washers after three days of the experiment. But at an applied potential $50 \mathrm{mV} V_{S C E}$, 316L SS showed a localized corrosion attack under the crevice washers. Thirty three out of forty (33/40) crevice sets showed the crevice corrosion attack as shown in (Figure 2). The 316L SS sample was removed after $\sim 8 \mathrm{~h}$ and $19 \mathrm{~min}$ of the experiment.

In test No. 5, the applied potential was increased from 50 to $200 \mathrm{mV} V_{S C E}$, 316L SS showed a localized corrosion attack under the crevice washers as shown in (Figure 3) Thirty three out of forty (33/40) crevice sites showed crevice corrosion attack. The number of corrosion sets in 316L SS at applied potential 50 and $200 m V_{S C E}$ is similar but the crevice corrosion attack on $316 \mathrm{~L} S \mathrm{~S}$ sample at $50 \mathrm{mV} V_{S C E}$ took more time to form which means the corrosion rate value for $316 L S S$ at $200 m V_{S C E}$ is higher than the value of corrosion rate for the same alloy at applied potential $50 \mathrm{mV} V_{S C E}$.

Figure 4 shows the effect of different applied potentials on the behavior of the crevice corrosion current for $316 L$ SS in $3.5 \% \mathrm{NaCl}$ at room temperature $\left(25^{\circ} \mathrm{C}\right)$. It is observed that the current is almost constant with the time at applied potentials: $0.0,-50$ and $-200 m V_{S C E}$ which means that there is no crevice corrosion attack for $316 L$ SS in this range of applied potentials. The crevice corrosion in the samples at applied potentials: $0.0,-50$ 
Table 2. Crevice corrosion susceptibility results for $316 L$ SS at different applied potentials in $3.5 \% \mathrm{NaCl}$ solution at room temperature $\left(25^{\circ} \mathrm{C}\right)$ at torque value $=2.5 \mathrm{in} \mathrm{lbf}$.

\begin{tabular}{cccc}
\hline Test No. & Applied potential $\left(m V_{S C E}\right)$ & Time $(k s)$ & Corrosion attacks \\
\hline 1 & -200 & 259.2 & No \\
2 & -50 & 259.2 & No \\
3 & 0.0 & 259.2 & No \\
4 & 50 & 30.24 & Yes $^{*}\left(33 / 40^{* *}\right)$ \\
5 & 200 & 2.220 & Yes $_{(33 / 40)}$
\end{tabular}

${ }^{*}$ Yes $=$ corrosion; ${ }^{* *} \mathrm{n} / 40=$ number of crevice corrosion sets for the total number of sets.

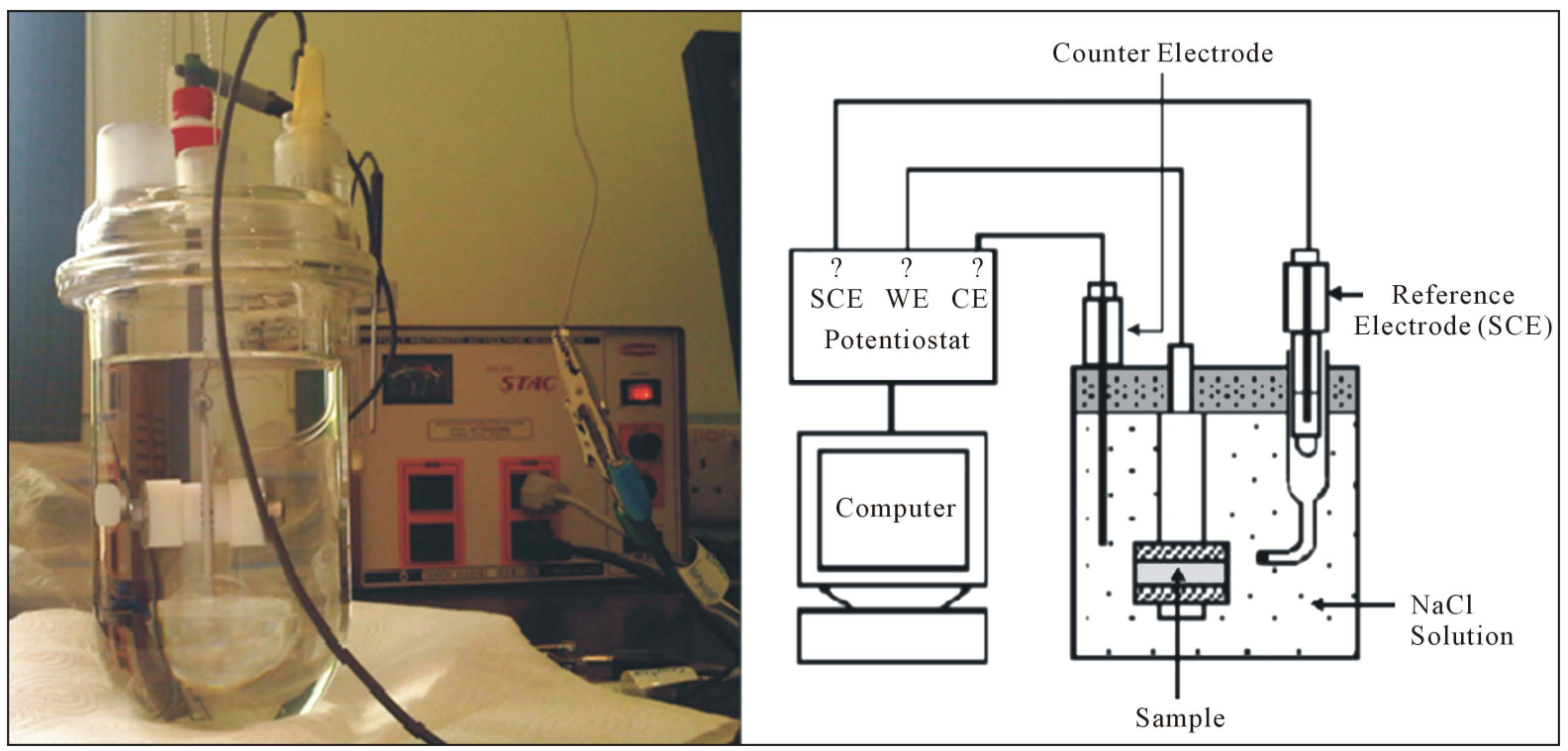

Figure 3. Schematic and photograph of corrosion cell used in experiments.

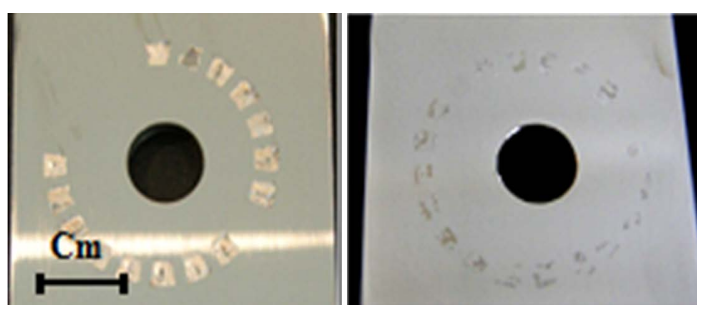

(a)

(b)

Figure 4. Crevice corrosion attack for $316 L$ SS sample in $3.5 \% \mathrm{NaCl}$ at room temperature $\left(25^{\circ} \mathrm{C}\right)$ after the experiment (a) at applied potential $=50 \mathrm{~m} V_{S C E}$, (b) at applied potential $=200 \mathrm{mV} V_{S C E}$.

and -200 $m V_{S C E}$ weren't observed which means that alloy 316L SS is still passive in the bulk solution and was held several tens millivolts below the crevice potential [14]. According to IR-drop theory, during the induction period the inverse of equation $I R>\Delta \varphi^{*}$ to $I R<\Delta \varphi^{*}$ is hold.

At applied potentials $=50$ and $200 m V_{S C E}$, the current increased with time. This is in agreement with Cho et al. [15] who found that the susceptibility to crevice corrosion decreases as $E_{\text {appl }}$ becomes nobler.

The magnitude of the $I R$ voltage between the bottom and opening of the crevice is greater than $\Delta \emptyset^{*}$ upon application of $E_{\text {appl }}$. Increasing the applied potential from $50 m V_{S C E}$ to $200 m V_{S C E}$ leads to decrease the induction 
period as shown in Table 3.

\section{XPS Measurement for 316L SS after Corrosion}

XPS measurements have been carried out for identifying the constituent species of corrosion products, which formed on the surface of $316 \mathrm{LSS}$ in $3.5 \% \mathrm{NaCl}$, at room temperature $\left(25^{\circ} \mathrm{C}\right)$ at $200 \mathrm{mV} V_{S C E}$. The formation of $\mathrm{Fe}_{2} \mathrm{O}_{3}, \mathrm{CrO}, \mathrm{MoO}_{3}, \mathrm{MoCl}_{3}$ and $\mathrm{NiO}$ compounds were found as shown in (Figure 5). It is expected that the presence of molybdenum can prevent the raising of corrosion speed through forming $\mathrm{MoO}_{3}$ oxide layers preventing flux of $\mathrm{OH}^{-}$and $\mathrm{Cl}^{-}$ions into films and pits [16].

\section{The Morphology of the Corroded Surface under the Washer Tooth}

Three different regions can be seen at corrosion area under each washer teeth as shown in (Figure 6). The first region (the passive region) extended from the crevice mouth to the $x_{\text {pass }}$ boundary. The second region (active region) started at $x>x_{\text {pass }}$ and extended to $x_{\text {lim }}$. The third region (etched region) extended from $x_{\text {lim }}$ to the crevice set center. The $x_{\text {lim }}$ boundary separating the latter two regions is diffuse and, unlike the $x_{\text {pass }}$ boundary, is not readily identified in the photograph. These three regions were observed on 316L SS at applied potential 50 and 200 $m V_{S C E}$. This distribution of the corrosion is in agreement with IR-drop theory which predicts the most severe attack at intermediated distance from the crevice mouth [10]-[12].

\section{Potentiodynamic Polarization Measurement}

Potentiodynamic polarization curve based on ASTM G5-94 [13] was recorded, with a scan rate of $0.1667 \mathrm{mV} / \mathrm{s}$, on $316 L \mathrm{SS}$ in $3.5 \% \mathrm{NaCl}$ solution at room temperature using a potential range from -600 to $1200 \mathrm{mV} V_{S C E}$ as shown in (Figure 7). The figure shows three distinguished regions, passive, active and transpassive.

In the active region, the behavior of the metal shows an increase in the applied potential causes a correspondingly rapid increase in corrosion rate. When the applied potential is increased sufficiently, the corrosion rate suddenly decreases. This behavior corresponds to the beginning of the passive region. $\mathrm{Fe}_{2} \mathrm{O}_{3}, \mathrm{CrO}, \mathrm{MoO}_{3}$, and $\mathrm{NiO}$ compounds play roles to protect $316 \mathrm{~L}$ SS. In the passive region, there is a fluctuation in the current density

Table 3. Induction period values for $316 L$ SS at different applied potentials in $3.5 \% \mathrm{NaCl}$ at room temperature $\left(25^{\circ} \mathrm{C}\right)$.

\begin{tabular}{cc}
\hline Applied potential $\left(m V_{S C E}\right)$ & Induction period (s) \\
\hline 50 & 525 \\
200 & 60 \\
\hline
\end{tabular}

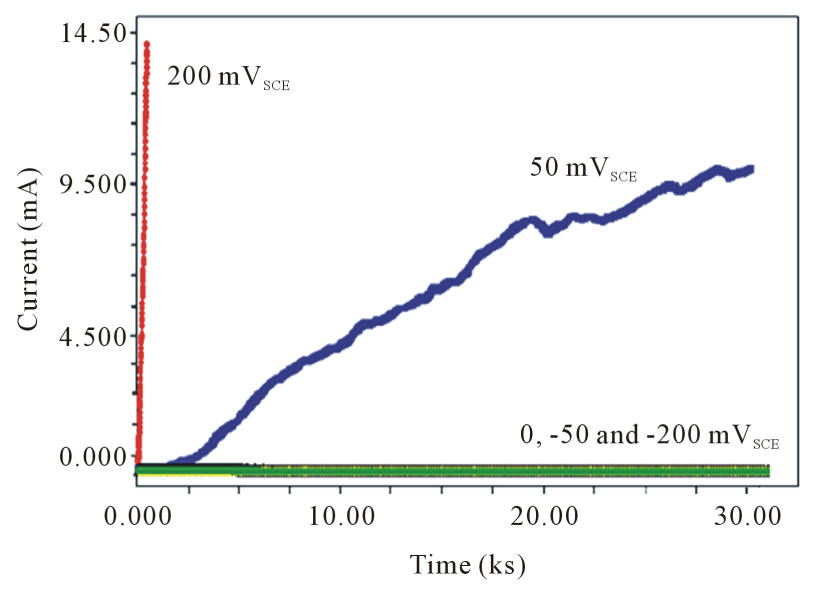

Figure 5. Measured current with time for 316 SS sample at different applied potential in $3.5 \% \mathrm{NaCl}$ at room temperature $\left(25^{\circ} \mathrm{C}\right)$. 

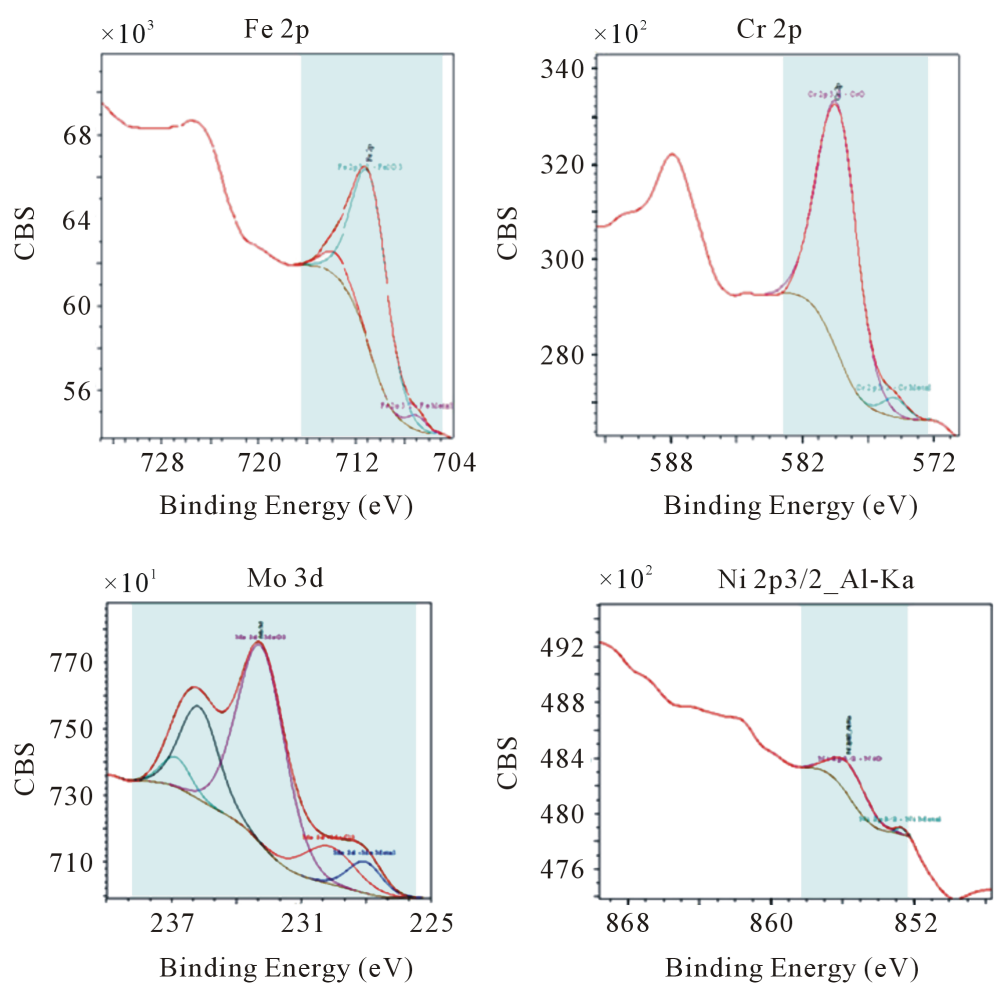

Figure 6. X-ray spectra obtained for $\mathrm{Fe}, \mathrm{Cr}$, Mo and $\mathrm{Ni}$ on $316 \mathrm{SS}$ surface after corrosion in $3.5 \% \mathrm{NaCl}$ at $200 \mathrm{mV} V_{S C E}$ at room temperature $\left(25^{\circ} \mathrm{C}\right)$.

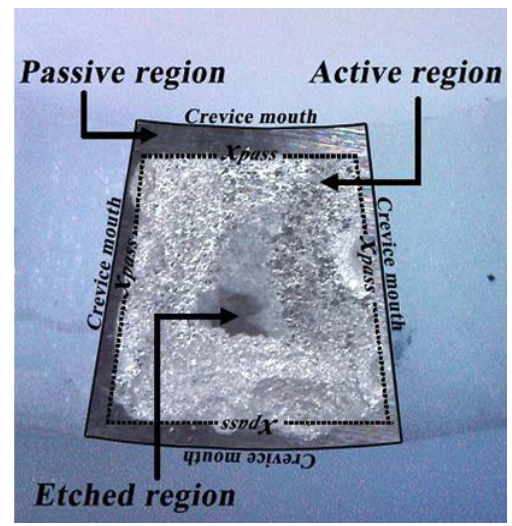

Figure 7. Photograph of the crevice set after the experiment of 316 stainless steel alloy in $3.5 \% \mathrm{NaCl}$ at $E_{a p p l}=$ $50 m V_{S C E}$ at room temperature $\left(25^{\circ} \mathrm{C}\right)$ (Magnification: $\times 70)$.

values from $77.38 \mathrm{mV}$ up to $476.2 \mathrm{mV}$ and there is more than one corrosion potential appeared indicating the unstable passive system. The stability of the film which formed on the alloy surface decreases with the applied potential increasing. A competition between corrosion and re-passive processes happened. At a very high applied potentials, the corrosion rate begins to increase with increasing potentials in a region called the transpassive region, where the protective passive film is thermodynamically unstable.

Included in the plot of (Figure 7) are various terms used to define the behavior of 316L SS alloy. Corrosion potential $\left(E_{\text {corr }}\right)$ and corrosion current $\left(i_{\text {corr }}\right)$ values were extracted from the potentiodynamic polarization plot. The average values $E_{c o r r}, I_{c o r r}, \beta_{a}$ and $\beta_{c}$, from polarization curves are presented in Table 4 . The value of $\beta_{a}$ is 
greater than $\beta_{c}$ which means that the alloy 316L SS prone to passivity [17].

\section{Effect of Scan Direction on 316L SS}

Figure 8 shows the polarization curves for 316L SS sample after scanning in two directions, from active to passive and vice versa, using scan rate $=0.1667 \mathrm{mV} / \mathrm{s}$ in $3.5 \% \mathrm{NaCl}$ at room temperature. The polarization curves are not similar for scanning from active to passive and passive to active directions for $316 \mathrm{~L}$ SS sample.

At scan direction from active to passive Figure 9, more than one corrosion potential appeared this is an indication of an unstable passive system. The stability of the film formed decreased with increase in the applied potentials. At scan direction from passive to active, the value of $E_{\text {corr }}=-530 \mathrm{mV}$. This value is lower than $E_{\text {corr }}$ for the alloy scanning from active to passive $(-135.4 \mathrm{mV})$. This may be attributed to the instability of the passive film.

\section{Conclusions}

- Crevice corrosion and the value of current with time for 316L SS increased with applied potential increasing.

- The values of induction period decreased with applied potential increasing, which means the growth of crevice corrosion becomes faster with applied potential increasing.

- XPS measurements show that the $\mathrm{Cr}$, Fe and Mo compounds resulting from crevice corrosion play an important role in protecting $316 L$ SS alloy.

Table 4. Electrochemical data resulted from polarization curve for $316 \mathrm{~L}$ SS immersed in $3.5 \% \mathrm{NaCl}$ at room temperature.

\begin{tabular}{cccccc}
\hline$E_{\text {corr }}(\mathrm{mV})$ & $I_{\text {corr }}\left(\mathrm{A} / \mathrm{cm}^{2}\right)$ & $\beta_{a}(\mathrm{~V} /$ decade $)$ & $\beta_{\mathrm{c}}(\mathrm{V} /$ decade $)$ & $E_{\text {pass }}(\mathrm{mV})$ & Corrosion Rate (mpy) \\
\hline-135.4 & $90.84 \mathrm{e}-9$ & 0.338 & 0.138 & 250 & $41.12 \mathrm{e}-3$ \\
\hline
\end{tabular}

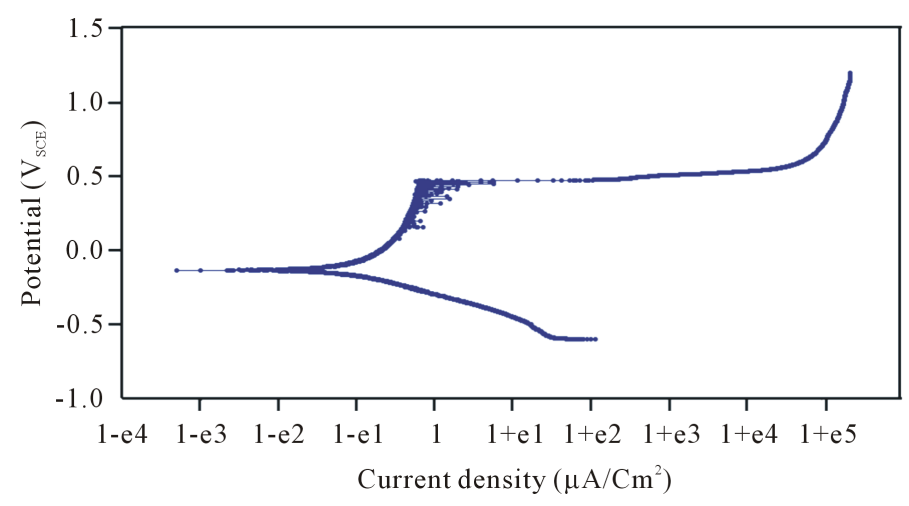

Figure 8. Potentiodynamic polarization curve for 316 SS with $3.5 \%$ $\mathrm{NaCl}$ at room temperature.

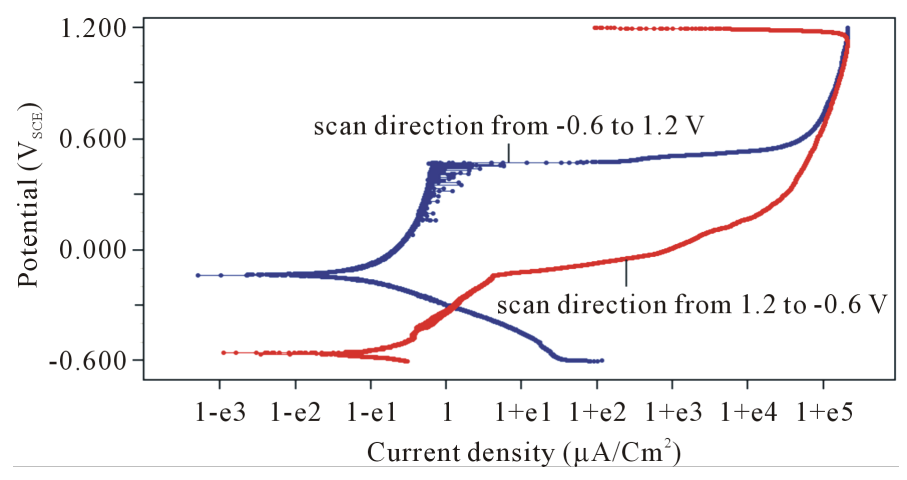

Figure 9. Effect of potential scanning direction on the potentiodynamic polarization curve of $316 \mathrm{~L}$ SS sample in $3.5 \% \mathrm{NaCl}$ at room temperature $\left(25^{\circ} \mathrm{C}\right)$. 
- The crevice corrosion occurred in the intermediate area under the crevice in agreement with IR theory.

\section{Acknowledgements}

This work was financially supported by KACST, Saudi Arabia. The authors wish to thank Prof. Hamad A. AlTuraif.

\section{References}

[1] Nicastro, D.H. (1997) Failure Mechanisms in Building Construction. ACSE. http://dx.doi.org/10.1061/9780784402832

[2] Al-Zahrani, A.M. and Pickering, H.W. (2005) Electrochim. Acta, 50, 3420.

[3] Cho, K. and Pickering, W. (1990) Demonstration of Crevice Corrosion in Alkaline Solution without Acidification. Journal of the Electrochemical Society, 137, 3313-3314. http://dx.doi.org/10.1149/1.2086211

[4] Fontana, M.G. (1986) Corrosion Engineering. 3rd Edition, McGraw-Hill Book Co., New York.

[5] Sundararajan, T., Akiyama, E. and Tsuzaki, K. (2005) Hydrogen Mapping across a Crevice: Effect of Applied Potential. Scripta Materialia, 53, 1219-1223. http://dx.doi.org/10.1016/j.scriptamat.2005.08.016

[6] Watson, M. and Postlethwaite, J. (1990) Numerical Simulation of Crevice Corrosion of Stainless Steels and Nickel Alloys in Chloride Solutions. Corrosion, 46, 522-530. http://dx.doi.org/10.5006/1.3585142

[7] Cho, K. and Pickering, H.W. (1991) The Role of Chloride Ions in the IR > IR ${ }^{*}$ Criterion for Crevice Corrosion in Iron. Journal of the Electrochemical Society, 138, L56-L58. http://dx.doi.org/10.1149/1.2085386

[8] Pickering, H.W. (2003) Important Early Developments and Current Understanding of the IR Mechanism of Localized Corrosion. Journal of the Electrochemical Society, 150, K1-K13. http://dx.doi.org/10.1149/1.1565142

[9] Abdulsalam, M.I. (2005) Behaviour of Crevice Corrosion in Iron. Corrosion Science, 47, 1336-1351. http://dx.doi.org/10.1016/j.corsci.2004.08.001

[10] Pickering, H.W., Cho, K. and Nystrom, E. (1993) Microscopic and Local Probe Method for Studying Crevice Corrosion and Its Application to Iron and Stainless Steel. Corrosion Science, 35, 775-781. http://dx.doi.org/10.1016/0010-938X(93)90215-3

[11] Xu, Y., Wang, M. and Pickering, H.W. (1993) On Electric Field Induced Breakdown of Passive Films and the Mechanism of Pitting Corrosion. Journal of the Electrochemical Society, 140, 3448-3457. http://dx.doi.org/10.1149/1.2221108

[12] Xu, Y. and Pickering, H.W. (1993) The Initial Potential and Current Distributions of the Crevice Corrosion Process. Journal of the Electrochemical Society, 140, 658-668. http://dx.doi.org/10.1149/1.2056139

[13] ASTM G 5-94 (2009) Standard Reference Test Method for Making Potentiostatic and Potentiodynamic Anodic Polarization Measurements.

[14] Kelly, R.G. and Stewart, K.C. (2001) Combining the Ohmic Drop and Critical Crevice Solution Approaches to Rationalize Intermediate Attack in Crevice Corrosion. In: Luo, J.L. and Rodda, J.R., Eds., Passivity of Metals and Semiconductors, The Electrochemical Society, Pennington, 547.

[15] Cho, K., Abdulsalam, M.I. and Pickering, H.W. (1998) The Effect of Electrolyte Properties on the Mechanism of Crevice Corrosion in Pure Iron. Journal of the Electrochemical Society, 145, 1862-1869. http://dx.doi.org/10.1149/1.1838568

[16] Razavi, G.R., Gholami, H., Zirepour, G.R., Zamani, D., Saboktakin, M. and Monajati, H. (2011) Study Corrosion of High-Mn Steels with Mo in 3.5\% NaCl Solution. 2011 International Conference on Advanced Materials Engineering IPCSIT, 15, 36.

[17] Mareci, D., Romaş, M., Căilean, A. and Sutiman, D. (2011) Electrochemical Studies of Cobalt-Chromium-Molybdenum Alloys In Artificial Saliva. Revue Roumaine de Chimie, 56, 697-704. 